\title{
Historiography as a Tool for Nationbuilding: The Case of Turkey
}

\author{
Ulus Yapımında Bir Araç Olarak Tarih Yazımı: Türkiye’nin Durumu
}

\begin{abstract}
Armand SAĞ $\breve{G}^{*}$
Abstract: Almost every country in the world is based upon nationalism. Some are based on a spiritual unity, while others focus on an ethnic or racial background. In all of these theories, there is the element of creating an unity through the process of nation-building. In this process, one can use multiple sources. Among these are songs, poems, writings, historiography and much more. In particular the case of historiography is emphasized in this article as historiography can be best implemented by using history text books for education. In this way, generations of school children can enjoy historiography that will make them grow into a unity with their fellow countrymen. In the case of Turkey, this tool of historiography is used to depict a new nation. I argue that this image of the nation is not based upon ethnicity, racial background, nor even linguistics or religion but mainly on geography. And in order to create a geographical basis, historiography was used as a tool to promote the military glorification of Anatolia. The strong focus on Anatolia also meant neglecting other geographical regions, of which the Balkans seem to be the most neglected, due to the military humilitation the Turks encounted in those regions.
\end{abstract}

Keywords: Nation-building, historiography, Turkey, Balkans, Anatolia, geography, military glorification

Özet: Dünyanın hemen hemen her yerinde, ülkeler ulus veya milliyetçilik üzerinde kurulmuştur. Bazı ülkeler bir etnik kimliğe veya ırksal geçmişe odaklanarak ulus oluşturmuştur, yine başkaları manevi bir birlik üzerine dayanmaktadır. Bu teorilerin tümünde, ulus sürecinde bir birlik yaratma unsuru vardır. Bu süreçte, bir çok araç kullanmak mümkündür. Örneğin bu araçlar arasında şarkı, şiir, yazı, tarih yazımı ve çok daha fazlası vardır. Tarih yazım bilimi halkı bir şekilde eğitmek için en uygun araçtır, eğitimde kullanılan tarih ders kitaplarıyla ulusun birçok özelliğini yeni nesillere aktarmak mümkündür. Bu yüzden, bu makalede özellikle Türk tarih yazım metodolojisi üzerinde durulmuştur ve özellikle tarih okul kitaplarında var olan Türk tarih yazım bilimine bakılmıştır. Tarih yazımına bakarak özellikle Türkiye'nin durumu kaleme alınmıştır. Bu çalışmamda Türkiye’deki ulus anlayışının imajının etnik, ırk, dil veya din üzerine değil de coğrafya üzerinde kurulduğunu tartışıyorum. Bu coğrafi temel oluştururken özellikle Anadolu’nun askerî öneminin yüceltildiğini ve vatan olarak gösterildiğini görmekteyiz. Türk tarih yazım geleneği Anadolu’ya odaklanırken başka bölgeleri istenilen ölçülerde ele almadığı görülmektedir ki Türklerin Balkanlar’da uğradıkları yenilgiler bunun en göze batan örneklerinden biridir.

Anahtar Sözcükler: Ulus oluşturmak, tarih yazımı, Türkiye, Balkanlar, Anadolu, coğrafya, askeri yüceltme

This preliminary research will try to shed a light concerning the use of Turkish historiography with the aim of inspiring others to focus more on this neglected topic of historiography in the process of nationbuilding. The Balkans are a troublesome region, especially for those countries that have a direct link with the region but are unable to embrace it within their historiography

\footnotetext{
* Drs., Institute for Turkish Studies (Utrecht - the Netherlands), Research Department, History, a.sag@turksestudies.org \& PhD. fellow, Tilburg University (Tilburg - the Netherlands)
} 
due to the process of nation-building. Turkey is one of these countries in respect to the Balkans. In Turkish historiography the aspect of the Balkans is almost entirely neglected. This paper is written with an aim of explaining why this is the case. I argue that the neglect of the Balkans in Turkish historiography was a direct consequence of the process of nationbuilding in Turkey. Nationbuilding in Turkey is not centred upon ethnicity, nor upon racial or religious factors but upon a geographical concept to create unity.

Nationbuilding as a way to create unity in a country is no new problem. Many countries are struggling with their own processes of nationbuilding and how they want to implement this onto their society in order to create a nation state. However, the struggle is different for many countries and the situation is, of course, also very different in each individual country. The problems involving nationbuilding are found not only in newly established countries but also in those states established centuries ago.

All countries, regardless of when they were established as a sovereign state, are now included in the immense processes of globalization and are therefore desperately trying to find a new political identity. This process of finding a new political identity has lead to various developments in each country; the most notable cause of which was the rise of nationalism in the centuries following the French Revolution of 1789.

\section{Introduction}

Since the emergence of the concept of a 'nation', entire states have adopted this understanding of some people living within a geographical region belonging to one common origin and of carving out their own 'nations'. In the nineteenth century the smaller German states formed one nation, or 'Kulturnation' to speak in the terms of Frederich Meinecke (1922), without actually being one unified state (Iordachi, 2006). In the nineteenth century, especially after De Gobineau (1853-1855), it was widely believed that the concept of 'nation' was interchangeable with that of 'race' because it was widely accepted that 'nation' was carved out through descent (Hewitson, 2006). In order to do this, the forgers of these new 'nations' had to invent myths, traditions, a suitable history, cultural trademarks and linguistic commonality (Anderson, 1983; Hobsbawm \& Ranger, 1983; Hobsbawm, 1990; Smith, 2009). Consequently, historiography became an important aspect for these forgers of 'new nations'.

After the nineteenth century, most notably from the 1920's and 1930's onwards, the concept of 'nation' became intermingled with other phrases. Two important and serious scholars of nationalism, Carlton Hayes (1931) and Louis Snyder (1954), within that specific time period were emphasizing the concept of 'nation' with a modern, secular content of nationalist ideologies and its close relationship to rationalism and liberalism (Smith, 2009). To this effect nationalism was seen as a term close to secularism, rationalism and liberalism. This was a radical change from De Gobineau (1999), who was against modern ideologies like republicanism within a 'nation' but was an advocate for 'race'. In both De Gobineau as in Hayes' theory of 'nation', historiography played an important role; for example by linking the British 'nation' to the myth of a 'honest and righteous King Arthur and his Knights of the Round Table' (Loomis, 1956; Thorpe, 1966; Higham, 2002). According to this latter theory, you could not be entirely free unless you had your own nation state. But even this has been differently interpreted in different regions of the world. In the west, the nation has basic components for example, historic territory, legal-political community, legal-political equality of members, and a common civic culture and ideology. Due to the political power of the west, most countries in Western Europe and America have adopted this concept; along with some non-western concepts of national identity. However, this western concept has not been able to 
'convince' Eastern Europe and Asia of this model in which the individual could choose to be part of a nation. According to Anthony D. Smith (1991), these regions of Eastern Europe and Asia historically challenged the dominance of the Western model and added significant new elements, more attuned to the very different circumstances and trajectories of non-Western communities. In this model of Eastern Europe \& Asia, an individual remained a part of the nation in which the individual was born, regardless of what nation the individual chooses to be a part of.

In this process of creating a 'nation', or the process of nationbuilding, one aspect was common to both the theories of De Gobineau and Hayes: the belief in a historical descent (Smith, 2009). While individual nations might come and go, a 'nation' as a historical community was eternal; and the historiography to support this was accordingly formulated. De Gobineau stated that there were only ten great civilizations in world history and all of them were derived from the Aryan race, and in doing so he placed an emphasis upon certain historical events, while completely neglecting others (Cassirer, 2009; Collins, \& Gobineau, 2010).

According to Smith (2009) it is typical for a state to formulate the grand narratives of the national history and to select its heroes and saint. This selective history was meant to put an emphasis upon certain myths, traditions, suitable history, cultural trademarks and linguistics (Dixon, 2011). Therefore historiography became an important aspect of the newly established nation state, as a factor both in emphasizing and neglecting. The states focused on earlier times in order to depict an ancient 'golden age'. During this process an exemplary golden age was defined. In this defining process, historiography plays an undoubted role as the main factor employed to select or to neglect parts of the national history in order to create a 'nation' in which people feel united and to be a part of the same community.

In both cases, the need to invent or to place a large emphasis upon myths, traditions, suitable history, cultural trademarks and linguistic commonality was imminent. Therefore historiography became an important aspect of the newly established nation state. These states focused on earlier times in order to depict an ancient 'golden age'. According to Smith (2009) it is typical for a state to formulate the grand narratives of the national history and select its heroes and saint. During this process an exemplary of a golden age is to be defined (Smith, 2009, 36). In this defining process, historiography plays an undoubted role as the main factor employed to select and to neglect parts of the national history.

\section{The Concept of 'Nation'}

Although Smith contests the idea that "the nation was perennial", there is a discussion about the definition of 'nation'. In the nineteenth and early twentieth century the terms 'nation' and 'race' became interchangeable but an obvious definition was lacking. The 'nation' was everywhere and in every period. Ancient Egyptians, Assyrians, Persians, Greeks, not to mention Indians, Chinese and Japanese were all 'nations', when they were not 'races' (Smith, 2009). The main point of 'natio', was that it was natural and therefore perennial and primordial. Smith $(2009,3)$ had this to say about this view:

"While individual nations might come and go, 'the nation' as a category and historical community was eternal, an historical datum whose origins and lineaments could ultimately be traced to human biology, but which manifested itself as a specific type of socio-cultural community. Of course, not all observers accepted this popular, and crudely nationalist, view".

Smith (2009) maintains that although 'nations' are partly forged by political institutions, over the long term they require ethno-cultural resources to create a solid community. He is contested by 
Ernest Gellner (1983, 7), who has formulated two simple (but temporary) definitions:

1) "Two men are of the same nation if and only if they share the same culture, where culture in turn means a system of ideas and signs and associations and ways of behaving and communicating.

2) Two men are of the same nation if and only if they recognize each other as belonging to the same nation. In other words, nations maketh man; nations are the artefacts of men's convictions and loyalties and solidarities (sic)".

In the discussion between Smith and Gellner, the former has also stated that the latter's definition of the concept of the nation is not useful because "[n]either 'will' nor 'culture' by themselves can provide useful definitions. The reason is the same: they both bring in far too rich a catch” (Smith, 2003, 21).

According to Gellner, the concept of 'nation' is in accordance with the three main eras in history. In the first era, the pre-agrarian or hunter-gatherer stage, the people did not form states or a political entity. Hence the possibility of forming a nation was not possible. In the second era, the agrarian stage, most people were part of a society and most had a state of their own. The possibility of forming a nation was possible during this stage, but it did not occur. In the third and final stage, the industrial era, the nation state became inescapable (Smith, 2003). Smith $(2009,5)$ adds to this that, "it was nationalism that invented nations where they did not exist; and, whereas nations had no place in earlier 'agro-literate' societies with peasant masses ruled by tiny elites, they now became not merely a sociological necessity but positively functional for industrial modernity".

Although Eriksen (1993) refrains from discussing the various meaning of 'nations', he does say that a nation is put together by putting an emphasis upon cultural similarities. By putting boundaries between cultural trademarks, it also puts other cultures outside of this concept.

Both Gellner and Smith agree that the concept of 'nation' could not have survived without a strong modern industrial era to cope with the mass. In earlier times the elite did not see themselves as equals of the peasants, but in later industrial times this segregation became vague since the mass was working with the elite, and not just for them. However, they disagree in what it requires in addition; ethno-cultural sources or ethno-symbolism, will and culture. The discussion is enriched by Eriksen (1993, 90), who joins this scholarly debate by formulating the essence of the 'nation':

"A nation-state, therefore, is a state dominated by an ethnic group, whose markers of identity (such as language or religion) are frequently embedded in its official symbolism and legislation".

Eriksen pretty much summarizes both the definitions of Smith and Gellner by bringing it back to the basic elements to which a nation (or nation-state) is to be bound. According to Eriksen these elements are the markers of a dominant ethnic group; such as language and religion. Now that the 'nation' is defined in accordance with the theory of Eriksen, the definition of 'nationbuilding' is to be established.

There are more nationbuilding-models among scholarly theorists of nationalism. According to Smith, the classical nationbuilding-model placed a strong emphasis on the political nature of the nation and the active role of citizens as well as their leaders in the construction of this nation. Within this classical model five aspects are applied (Smith, 2003).

In addition to this classical nationbuilding-model, there are two other major theories. First of 
all, it can refer to state-building that is combined with national integration and mobilization which requires the formation of a national cultural and political identity that clearly differentiates it from its neighbors (Smith, 1991). The second thought about 'nation - building' is that it is intrinsic to the project of social and political modernization within a nation (Smith, 2009). In practice it firstly means that one dominant culture tries to bring together all the other aspects.

Trying to implement one dominant culture upon a society to create unity is something almost all countries have done in order to create their own nation state. To give just one example of the implementation of the process of nationbuilding, one can look at Eugen Weber's publication 'Peasants into Frenchmen: The Modernization of Rural France, 1870-1914':

"[...] that is why Haussmann, writing his memoirs in retirement, could refer to "our country, the most 'one' in the whole world," when France was still very far from one [...]. The myth was stronger than the reality.

Yet the reality was inescapable. And the reality was diversity. One reason believers in the essential unity of France ignored this most obvious fact may have been that they took that unity for granted. But as the century advanced the division between country and town began to attract comment. The economist Adolphe Blanqui, who traveled a great deal through darkest France [...] was one of the first to insist on it. In his preliminary findings, published in 1851, Blanqui noted: "Two different peoples living on the same land a life so different that they seem foreign to each other, though united by the bonds of the most imperious centralization that ever existed" (Weber, 1976, 7).

The above example of France and its process of nationbuilding shows that after 1870 when the "schoolbooks of the Third Republic taught: one people, one country, one government, one nation, one fatherland", there was in fact no such thing. It was only in the 1840s, some mere 30 years earlier, that a citizen from Paris mused that one did not need "to go to America to see savages" referring to the peasants of the Burgundian countryside (Weber, 1976). Nonetheless this was used to depict the French as a nation state when it still was on the way to becoming one. But France was not alone in this; almost all Europe was obsessed with the creation of their own nations. Especially in the regions that had a very diverse population and a locally bound loyalty, such as in Germany and Italy in the second half of the nineteenth century, the idea that "each people had its unique voice and style, its original culture and individuality [...] struck a powerful chord among the small coteries of intellectuals and middle classes of the different ethnic communities and networks in these areas" (Smith, 2009). These intellectual leaders then tried to create more unity, in Italy and Germany this resulted in unification of the smaller states into one major Italian and one major German nation state.

Yet another example could be that of Great-Britain, where the British ethnic populations are the product of considerable social intercourse and cultural fusion between Anglo-Saxon, Danish and Norman elements (Smith, 1991). Nonetheless a common myth of 'British descent' was proclaimed in order to subdue the various ethnic groups of Britain into the dominant culture. Patrick Geary $(2003,173)$ sums it up as following:

"Others managed to survive beyond the lives of their founders, to absorb other, rival groups, and to create a unifying myth of peoplehood, a myth that projected the people back into a distant, glorious past and justified claim for a great and powerful future".

One thing that catches the eye is that by projecting people back into a distant and glorious past, some phases are left out. Therefore the process of nationbuilding seems to develop hand in hand 
with the tendency of nation-builders to leave out, neglect or simply not to mention some aspects of their own history because it would damage the process of nationbuilding. This is our main focus in looking at the process of historiography in Turkey.

According to Keyder $(2005,6)$ "[t]here are silences in every nation's history which belie an active effort to forget". In Britain there was much attention given to the "Anglo-Saxon myth, which traced English origins back to the Germanic tribes and their ancient liberties and 'free' institutions" (Smith, 1991). However, building a nation through the promotion of one dominant culture that 'needs' to be homogenic throughout the state, indirectly means that other minor cultures need to be left out, or at least to be minimized in order to be seen as a regional subculture of the dominant national culture. In Britain this effectively means that the Scottish and Welsh cultural heritages are almost entirely neglected, whether or not by choice.

The same could be said of the Netherlands, where the aspect of slavery seems to be neglected (especially in relations to the former Dutch colonies of Suriname and the Antilles) in order to prevent the Dutch from experiencing feelings of guilt. This would effectively undermine the dominant idea of 'the glorious Dutch nation', as promoted by contemporary politicians (During 2006 the, at that time, prime minister of the Netherlands Jan-Peter Balkenende used the term 'VOC mentality' to describe the dynamic entrepreneurship of Dutch businessman on at least at four different occasions. VOC was the state-sponsored trade company that was responsible for much of the slave trade in the seventeenth and eighteenth century). Other countries like Spain, with the Catalans and Basques, and France, with the Huguenots, have also neglected some parts of their history in order to create unity among their people or within their country. In both cases, Spanish and French, this neglect concerned the neglect of some smaller minority cultures. Turkey seems to be no exception to this when it tried to promote the dominant Turkish culture in Anatolia and subsequently, whether or not intentionally, minimized the various other cultures that were (and still are) present in the region. Especially the different Kurdish cultures of Kırmancı and Sorani, just to name a few of the Kurdish tribal cultures that existed in Anatolia, have been seriously neglected as distinctive cultures and subsequently included as parts of the dominant entity (Türközü, 1985).

This aspect of nationbuilding therefore is summarized best when one speaks of the construction of the past through a dominant culture that has its foundation in history.

\section{Using Historiography for Nationbuilding}

The construction of the past in a country is directed and maintained by the political elite in a country, making the construction of the past (or historiography) a tool for nationbuildingpurposes. By using political socialization as well as popular socialization the task of ensuring a common public within one nation of public a mass (homogeneous) cultures can be done through government agencies (Almond, \& Pye, 1965; Smith, 1991, 11). The best example of this is notably through the system of education and the publication of history books that are used during the course of this education. These history books are to be seen as the official historiography of a nation. Through these books, the educational system is used to create a mass culture of homogeneous elements in which every citizen is regarded as being part of the nation state (Mathiez, 1939; Soboul, 1973; Weber, 1976; Gellner, 1983; Baycroft \&, Hewitson, 2006).

The most obvious is the socialization of myths, traditions, suitable history, cultural trademarks and linguistic commonality, which are achieved through compulsory, standardized, public mass education systems, through which the state authorities hope to inculcate national devotion and a distinctive, homogeneous culture, an activity that most regimes pursue with considerable energy 
under the influence of nationalist ideals of cultural authenticity and unity (Gellner, 1983; Smith, 1991, 16).

A well-maintained and effective centralized educational system is the key instrument in forming common cultural traits upon a society (Gellner, 1983, 89). The range will be much wider than art, novels or later even films. Other notable examples are not nearly as efficient as the educational system and the historiography employed within it. The mass nationalist education began with the French Revolution (1789) in which every peasant was regarded as a 'national citizen' and therefore received exactly the same education as the son of a notable (Weber, 1976; Smith, 1991). Prior to this, the children of a notable did not receive the same education as a peasant, rather a far more intensive education. The peasant did not receive that kind of education, if any (Smith, 1991, 58).

An important feature that appears when using the educational system as a tool to create unity and a nation state, is the aspect of neglect and emphasis within the state version of history. This is not surprising seeing that Smith (2009) claims 'nations' are partly forged through political institutions.

When one looks at different countries, we can clearly see the aspect of neglect in their educational system. For instance, after the Second World War the allies deported some twelve million Germans from their homes in Eastern Europe (Clark, 2006). The allies did this in order to provide Russia with the room to expand, since the Russians had aided the western allies against the Nazi's of Germany. The same Germans had negotiated with their Italian and Russian allies during 1939-1941 for a possible population exchange amongst themselves. This aspect of national history is accordingly neglected in all the above mentioned countries and in their education systems. This aspect of neglect is not confined to the European or Asian continents, even the United States of America has its unmentioned versions of history in its education systems. The most notable example is that of the native American Indians, the native inhabitants of the American continent, which have been reduced to a very insignificant part of the American population today (Heart, \& DeBruyn, 1998). In America this aspect of native Americans is not only downplayed within the educational system but the emphasis is also put on the various explorers that came to America. The explorations and navigational skills of explorers like Columbus are emphasized in such a strong way that everything is put into a different perspective. According to Heart, \& DeBruyn (1998) these explorers are seen as committers of mass massacre by the Indians, but this is entirely neglected in the current American education system.

Likewise we can see that Turkey is a country with many unresolved issues due to this kind of neglect and emphasis, but it is certainly not alone in this. Many countries have unresolved issues in their history. The problem of unresolved and highly disputed issues in national history is present in almost every country. In Japan the colonial past of the proud Japanese is also still unresolved (McCormack, 2009). Some of these unresolved issues have even been known to spiral out of control, like the Indian-Pakistani clashes of recent decades. These clashes even led to large-scale warfare between these two countries and the issue still remains unresolved. When the British left their colony of British-India, their their former colony subsequently divided into two states: India and Pakistan. These countries still have a troublesome relation with each other, one that includes multiple wars between them. The fate of the province Kashmir is still the subject of debate today (Adhikari, \& Kamle, 2010). Keyder (2005) emphasizes that there are silences in every nation's history which belie an active effort to forget.

To give an example of the implementation of neglect and emphasis, one can remember the case of France in Eugen Weber's publication 'Peasants into Frenchmen: The Modernization of 
Rural France, 1870-1914'. In France after 1870 the schoolbooks of the Third Republic taught: one people, one country, one government, one nation, one fatherland. In reality, there was no such thing. A mere thirty years prior, in the 1840s, a citizen from Paris mused that one did not need "to go to America to see savages" referring to the peasants of the Burgundian countryside (Weber, 1976). But the schoolbooks of the educational system put an emphasis upon the unity of the people and subsequently neglected the poorly educated peasants of the countryside; making it seem that the people of France were all one and were highly-educated.

But France is not alone in this; other parts of Europe also became struck with the ethnic nationalist preoccupation of creating a national identity through the process of education in the early nineteenth century. Just as we have seen earlier in this paper with Germany and Italy resulting in the unification of smaller states into one major Italian and one major German nation state.

\section{A Case Study of Turkey}

Turkey was in no way different from other parts of Europe or the world in trying to implement a model of nation and nationbuilding upon its inhabitants by means of education and historiography through school books. Promoting the dominant Turkish culture in Anatolia subsequently, whether or not intentionally, minimized the various other cultures that were (and still are) present in the region; just as is the case in other countries of the world. However, it needs to be said that Turkey started its own process of nationbuilding at a time when other countries had nearly completed theirs, or at least realized solid ground from which they could develop further their nationbuilding, it became even harder for Turkey to implement its own process of nationbuilding (Geary, 2003). The main difference with other European nations that were powerful during the centuries prior to this time, like France and Britain, was that these WestEuropean countries began their process of nationbuilding years, decades, even centuries before.

Although the characteristics of Turkish historiography are such that there is much common ground with other countries, one exception is that Turkey started its process of nationbuilding fairly late, at the beginning of the twentieth century. The other processes of nationbuilding, in Great-Britain and France for example, began decades or centuries before (Geary, 2003). According to Weber (1976) the French started their process of nationbuilding in the early nineteenth century, while the British began theirs in the Middle Ages (Smith, 1991). For the Turks, this process was different because the ideas of nationalism first made their entrance into the Ottoman state through the minorities (McCarthy, 1997, 204; Hanioğlu, 2008, 51). The Greek mercantile colonies abroad made some Greeks far more aware of European ways and thoughts than most Ottomans and stimulated the rise of intellectual and political leaders who spread the ideas of nationalism, revolution and independence as early as the seventeenth and eighteenth century (Shaw, 1977, 17; Palmer, 1992, 82; Ortaylı, 2007, 96). The same could be said of the Serbs who were the first Ottomans to organize a nationalist uprising in 1804 (Hanioğlu, 2008). In Ottoman territory, citizens that were Muslims, like the Turks, were almost never bankers or traders due to Islam; which discourages Muslims from asking for interest and from making a profit from people's needs. Therefore loan bankers and mercantile colonies were the only ties Ottoman citizens could have with the rest of Europe, and all of these merchants were nonMuslims such as: Jews, Greeks, Armenians and so on (Shaw, 1991; İnalcık, 2002, 3; Quataert, 2006, 132). In the end even the headquarters of the Ottoman state bank was located in Paris and London (Zürcher, 2004, 66).

It was not until the early twentieth century that the Ottoman Turks turned to nationalism, some two to three centuries after the Ottoman minorities had turned to nationalism (Shaw, 1977, 
289; Kinross, 2002, 585). Therefore Turkish nationalism had a very different approach in comparison to other European nations such as France or Great Britain. In the outlines of Turkish nationbuilding and its genesis, the fact that the Ottoman minorities were already under the influence of nationalism played a big role. This clash between various communities that were already under the influence of their own nationalism and the nationalism that was trying to be implemented by the ruling class in the early twentieth century, was the main difference between Turkish nationbuilding and the process of nationbuilding in other European countries.

This became apparent during the transition from the Ottoman state to the Republic of Turkey, the main focus became to create unity through nationbuilding. This was mostly accomplished through a concept of the nation that was both historical and geographical as well as cultural. For example; the majority of the inhabitants of Anatolia, which was the only region that survived as a political entity after the Ottoman collapse after its defeat in the First World War, had a few common aspects. These aspects were forged into what was later to be called the 'Turkish nation' (Baykara, 2000). In this aspect the history of Turkey was not restricted to the modern Republic of Turkey (1923 to present), nor to its predecessor the Ottoman EmpireSultanate (1299-1922) and not even to its pre-predecessor the Seljuk Sultanate $\left(11^{\text {th }}-13^{\text {th }}\right.$ century). All these three states were more or less within the same geographical area of Anatolia (Jackson, 2005). But the aspect of Turkish history was put further into the past and by doing so the role of historiography as a part of the process that aimed for nationbuilding became imminent.

The historiography focused on Seljuk tribes, that were migrants from Central Asia to Anatolia and Turkish history followed this path back to Central Asia. The history of the various tribes of Central Asia, which lived as clans but with a similar culture and language, then became the main focus within the historiography of the new Republic of Turkey. According to this theory, the Turks were the direct and unmixed-uncontaminated descendants of the tribes who inhabited a territory in those distant lands of Central Asia (Keyder, 2005). By doing so, the historiography of the Turks did not only focus on Anatolia but also upon the Central Asian tribes. However, geographically the Central Asia tribes (the direct ancestors of the Turks) were brought to leave due to the major ecological transformation that altered the lands of their origin (being Central Asia) to be irreclaimable (Keyder, 2005). Anatolia seemed to fill this gap and centred the attention of Turkish historiography not on (Central) Asia but instead on Europe (Duran, 2005). This caused the first region of Europe to be inhabited by Turkish tribes, the Balkans, to be subsequently neglected and/or ignored in Turkish historiography.

\section{Turkish Historiography}

This geographical aspect of Anatolia in Turkish historiography was emphasized heavily in Turkey from 1923 onwards, and in a way it is still the core of the Turkish process of nationbuilding. The geographical focus on Anatolia was integrated in school books for generations of young Turkish students. These history schoolbooks are what we can call 'Turkish historiography', along with those scholars that support them. This qualification in no way is a judgment as to if this form of historiography is accurate or is wrong; that is up for discussion.

During primary education, the Turkish Ministry of Education assigns history books that are to be used within all history classes. These books are easily recognizable as the sentence 'Approved by the Ministry of Education' is clearly recorded (Su, \& Bülkat, 1961). These books are made up of 31 chapters, each with a different subject matter. If we look deeper into these text books in search for the geographical region of Anatolia and the importance given to it, we can see that the statistical model is Kâmil Su \& Galip Bülkat's Illk ve Orta Okullar İçin Resimlerle Tarih Atlası ('History Atlas with Pictures for Elementary and Middle Schools'; 
Ankara 1961). As a statistical model the content of this history text book occurs most frequently in a probability distribution within research on various Turkish primary education history schoolbooks conducted by this author in early 2012. Therefore Su \& Bülkat are the main focus within this section.

Not surprisingly, secondary education has more detailed history books. In these books, there are no less than thirty one chapters (Yıldız, 2006). Again, just like the books utilized in primary education, we can divide these chapters into chronologically parts without changing the order of the chapters. Just like the study dedicated to primary education in Turkey, this research will use İshak Yıldız's (Öğrenci Seçme Sınavı) ÖSS Tarih: Temel Kavramlar ve Bilgiler ('Student Selection Exams History: Basic Terms and Knowledge'; İstanbul 2006) as the statistical mode for this stage of Turkish education: subsequently secondary education.

As stated, the approval of history books by the Turkish Ministry of Education stops at high school. All universities in Turkey, either state universities or private universities, are free to devise their own curriculum. Therefore it falls outside the scope of this research. However, in Turkey high school graduates have to pass a special admission exam to enroll to an university. These exams are called 'Öğrenci Seçme Sınavı (ÖSS)' or 'Student Selection Exams' (İrem, 2009). These exams are made from questions that are prepared according to the history books that are used throughout secondary education. These questions can provide us with an important insight into which topics are regarded as important in Turkey.

The image of the nation through Turkish eyes becomes clear when one looks at the statistical data collected from the ÖSS in regard to geography in Turkish education. When we look at the 922 questions that have been asked to date (from 1985 until 2010) in the Turkish admission exams about history, we can see a couple of important aspects. For one, many chapters do not include a direct geographical focus but an implicit one. This is for instance the case with chapter nine concerning Ottoman culture and civilization; most of the questions relate to how the Ottomans ruled and controlled their lands. One can say that since the Ottomans had Anatolia among their provinces, this chapter can be seen as having a geographical focus on Anatolia. However, in this research these chapters have been discarded from having a geographical focus on Anatolia (Arıca, \& Yaşasınoğlu, 2010).

\section{A Plural Historiography}

But there is something that needs to be said in retrospect regarding the aforementioned Turkish historiography and the scholars that support it. As mentioned before, the most wealthy class of citizens in the Ottoman world were of non-Muslim and non-Turkish descent. This was caused mostly by the privileges in the banking and trade sectors for the non-Muslim minorities. Profiting from their wealth and their ties with foreign states, these minorities eventually carved out their own concept of nationalism. Due to their ties with foreign states, the minorities were able to come into direct contact with notions of nationalism. The Muslims and Turks within the Ottoman Empire were not in this position. So when the Turks eventually came into contact with the concept of nationalism, the common history was to be reinvented but due to the lack of financial wealth the number of intellectuals that were highly educated was few.

To overcome the lack of historiography among the Turks, the first political nationalists based their work primarily upon non-Turkish sources to create Turkish historiography (Shaw, \& Shaw, 1977, 261-262). The Anatolian philosopher Ziya Gökalp (Gökalp wrote in his essay that "he has researched his own background and that he has no Kurdish bloodline", adding that even if he had Kurdish blood this was of no importance because he "felt Turkish by his 
upbringing”; see Türkçülüğün Esasları (1923; reprint 2001), is seen as the 'father of Turkish nationalism' (1923; Berkes, 1959; Ünlü, \& Çotuksöken, 2001), while the Armenian linguist Agop Martayan Dilaçar was the first Secretary-General of the Turkish Language Society in Turkey (Dilaçar, 1936; Türkay, 1982). Even the theory about the Turkish language being the language from which all other languages descended, also known as the 'Güneş Dil' or 'Sun Language Theory', was work of the Austrian linguist Dr. Hermann F. Kvergić (1935; Lewis, 1999). His theory claimed that the Turkish language, through the Sumerian language, was the language from which all civilized languages derived, and soon he was given support by the founder and first President of the Republic of Turkey, Mustafa Kemal Atatürk.

The lack of Turkish scholars resulted in foreign scholars being employed and used to form a Turkish identity and this is also clear in Turkish historiography. The Danish scholar Vilhelm Ludwig Peter (1847-1927) along with the German-Russian scholar Friedrich Wilhelm Radloff (1837-1918) are regarded as the founders of Turkology, a scientific study of Turkish peoples. They also deciphered the Turkish Orkhon inscriptions in Central Asia, concluding that the Anatolian Turks of their day were the descendants of (or at least connected to) the ancient tribes of Central Asia. Their findings were incorporated in Turkish historiography.

This has led to current Turkish historiography stating that both Anatolia as well as the various tribes in Central Asia were all 'Turkish'. This caused some historians in Turkey to redefine the Central Asian tribes as 'Turkish (or Turkic) tribes' and the ancient Anatolian civilizations of the Sumerians and Hittites were promoted to being 'Proto-Turks' (Kurt, 1995). This was quickly adopted in the process of Turkish nationbuilding by celebrating the victories of the Seljuks in the distant past, for instance, the Battle of Manzikert on the $26^{\text {th }}$ of August 1071 which took place between the armies of the East Romans and Seljuks; the latter emerging as the victors and subsequently conquering Anatolia, and recording these aspects in school text books (Su, \& Bülkat, 1961; Yıldız, 2006; Arıca, \& Yaşasınoğlu, 2010). The Turkish history that is taught through these history school books in this era right after the founding of the Turkish Republic seems to represent Turkish historiography, which remains pretty consistent with the contemporary school text books of today, and which can be used to offer us an insight into which history is put forth through the process of nationbuilding in Turkey (see appendix).

Turkish nationbuilding seem to indicate historical-geographical criteria of the region of Anatolia as being being the 'homeland' of the Turkish nation and of a historical-cultural tie with the Central Asian tribes (Yıldız, 2006). Between these two regions of Anatolia and Central Asia, the former became increasingly more important as is summarized by Karaömerlioğlu (2010, 100):
"While the Turanist and Pan-Turkish varieties were often preoccupied with external Turks living in external territories, Anatolianism never mentioned them at all. Indeed, when they were mentioned, it was to show why it was impractical, irrelevant and impossible for any Turkish nationalist project to include Turks living outside Anatolia".

The other regions between, like the Middle East, or at the frontier, like the Caucasus and Balkans, were accordingly neglected; as they mostly still are today. Anatolia became the undisputed new 'homeland' of the Turks, which was odd seeing that "[t]he political and intellectual elites of the Ottoman Empire looked down on central and eastern Anatolia, the least developed part of the country-an attitude that would radically alter after the loss of the Balkans" (Üngör, \& Polatel, 2011, 23). 
Nonetheless, Turkish historiography has proclaimed Anatolia as its 'homeland' and the few flaws have been accordingly neglected. Central Asia was accordingly seen as a region that had been ecologically transformed in such a way that the lands of origin (being Central Asia) were so altered as to be irreclaimable. Although this theory proclaimed that the Turks were the direct and the uncontaminated descendants of the tribes who inhabited a territory in the distant lands of Central Asia (Keyder, 2005), this was brought back to a strictly historical-cultural tie. Through doing so, the geographical aspect of Turkish historiography's sole focus is on Anatolia.

The portrayal of Anatolia was of an undivided region with one common culture, but much ethnic diversity. Turks, Armenians, Arabs, Greeks, Jews, Laz, Kırmanci (and other Kurdish tribes), Zaza and many more ethnic groups were all supposed to derive from one Anatolian culture. Seeing that many of these groups had already formed their own concept of nationbuilding some two centuries earlier, many Christian nationalists were reluctant to agree that 'their' culture was just part of a 'common Anatolian' culture (Shaw, \& Shaw, 1977, 260). Because these ethnic minorities had come into direct contact with nationalism prior to the start of Turkish nationbuilding, they had their own views on nationalism. Some felt more connected with their own nationalism than with the newly created Turkish nation. For example, an ethnic Greek in Anatolia could have felt more connected to the Greek nation and subsequently dismissed the Turkish views on nationbuilding.

\section{History versus Historiography}

The struggle for a new Turkey has also gained attention through the (unresolved) questions in Turkish history due to its own historiography. There are some examples of clashes within historiography. These rebellions against the dominant view of Turkish nationbuilding have led to different perceptions on happenings that were later to become controversial political issues. One example is, for instance, the fate of the Assyrian minority in Turkey during the First World War. Although most Assyrians claim to have been victims of a genocide, a number of scholars such as Özdemir (2009) conclude that the Assyrians were displaced (or relocated) due to an armed uprising or violent revolt against the Ottoman state during the First World War (19141918) when many Turks were killed. Because there is not much attention paid in Turkey to this period, this issue remains disputed (Özdemir, 2009). Another example is the mass population exchange between Turkey and Greece. As a result, "about 400,000 Muslims were forced to move from Greece to Turkey, while at least 1,2 million Greek Orthodox Christians were either shifted from Turkey to Greece or, if they had moved already, told they could never return to their old homes" (Clark, 2006, xii). The issue remains unresolved as various communities still demand compensation for being relocated and having had to leave all of their possessions behind (Clark, 2006). Yet another example is that of the Pontus Greeks of North Turkey. According to Kurt (1995), they were sent into exile after their uprising during the First World War but the Pontus Greeks disagree, stating that they were victims of genocide. Two other examples may well be the most well known examples of unresolved issues in contemporary times. One is the Armenian question, which is comparable to that of the Assyrians and Pontus since there was an Armenian rebellion prior to the relocation (McCarthy et alii., 2006), while the other is the Cyprus issue. The latter is disputed because the Greek Cypriots claim that nothing was happening and the Turks 'out-of-the-blue' or 'suddenly' intervened with violence and occupied Cyprus in 1974, while Turkey claims the Turkish minority in Cyprus was being subjected to repeated Greek-Cypriot killings from 1963 onwards and in consequence it launched a humanitarian intervention (Ülger, \& Efegil, 2002).

These examples show that historiography plays an important role in nationbuilding, but also 
that the different parties emphasize or neglect certain elements to serve their own interests.

\section{Features of the Turkish Nation}

Turkey has two important features within its own image of the Turkish nation. Firstly, Turkey is seen as a militaristic state. From the beginning of the twentieth century, the new Republic of Turkey was portrayed to its citizens as a "military-nation" (Altınay, 2004). But this is not the most surprising aspect of it, as in the year 1999 (some 76 years later) the following was still being said by Turkish ministers:

"Turks have been known as a military-nation throughout history. The Turkish military is synonymous with Turkish national identity. Our military has won great victories, glory and honor for our nation" (Altınay, 2004).

And of course the defeats of this 'glorious Turkish military' cannot be fitted into this general picture. Therefore neglect within Turkish historiography seems to be the only option for the implementation of nationbuilding in Turkey. According to Altınay the core of Turkey today is still that it is a nation with a glorious, especially military, past.

This is not something unique. Countries like Japan, Germany and France, for example, all have (or had) a nationalist and militaristic self-image. For instance, Japan's controversial history textbooks still reinforce the absence of both any war guilt and any responsibility in Japan's nationbuilding. Scholar Daniel Nagashima points out that Japan is still reluctant to acknowledge its role as the aggressor because it sees it as something 'normal' (Nagashima, 2006). This is symbolic of its unwillingness to genuinely face up to its past.

Just like Japan, Germany also has a strong concept of militarization in its culture. Roger Chickering describes Germany as a country in which the military is 'the nation's highest source of pride.' And of course the reasons for this state of affairs were many and complex. It involved Germany's political institutions, its patterns of socio-economic growth, and the sorts of attitudes and habits of mind suggested by the word 'kultur'. In all events, the fact that the German Empire was born on the battlefields of France in 1870-71 was of considerable importance. The Franco-Prussian War credited the army as the symbol of Germany's national destiny, and it ensured that soldiers would have an elite position within German society (Chickering, 2008).

Yet another example is France, in which the role of the French Foreign Legion and the men that served in it, played an important role. It even became so that every man, regardless of his ethnic origin or country in which he was born; capable of speaking French could become a French citizen after serving in the French Foreign Legion. French militarism was especially present in the French colonies of Africa, in which the French intervened and used force more often than any other outside power. Scholar Robin Luckham singles out France's militarism in Africa because it promotes a military-industrial society combined with a certain ruling class and regime (Luckham, 1982).

So, the aspect of militarism is not unique. The second important feature is in the portrayal of a ethnically plural society. Each of these features separately, militarism as well as pluralism, is not new: most Asian countries (of which India is a very good example) have a pluralist selfimage. This is especially the case in Southeast Asia where millions of rural and indigenous people still live according to their own traditional ways without interference from the government (Colchester, \& Chau, 2011). Accordingly India has a plural society that is seen by some as the ideal of the plural society. In editor Baidyanath Saraswati's book 'Interface Of Cultural Identity Development', Indian civilization is described as being far different from other civilizations in the world due to its heterogeneity and its cultural diversity (pluralism). The 
emphasis is placed upon Indian civilization hosting several streams of migrant groups and communities from different parts of the world since the middle of the second millennium B.C.; referring to the advent of the Aryans, the Tibeto-Burman speaking Mongoloid groups, the Kushans, the Greeks, the Arabs, the Persians, the Huns, the Sakas and other Turks and the Mongols at different points in time. Subsequently this should testify to the pervasiveness of the migration process during successive periods of Indian history. According to scholar Momin (1996), the migrant groups and communities brought their respective traditions and behavior patterns from their native lands. This aspect of pluralism as a tool for nationbuilding is also not uncommon in most countries that are in the process of their nationbuilding.

However; when these two features are combined, as in the case of Turkey, it does in fact constitute something unique. According to Altmay, Turkey has a 'military culture' and constitutes a 'military nation' although this is a product of history as well as the artifacts of a century of practices and discourses (Altınay, 2004). Even after 1982, Turkish history textbooks of both primary and secondary education taught values such as nationalism, the unity and indivisibility of the nation, respect for authority and for militarism (Kerslake, 2010). The Dutch scholar Zürcher emphasizes that Turkey focuses mainly upon a state-centred Turkish nationalism and militarism during the process of nationbuilding (Zürcher, 2010). But on top of this, Turkey also has a plural society which is easily comparable with that of India. Both are regarded as regions to which many people migrated over the centuries. Greek, Hittites, Armenians, Romans, Persians, Macedonian, Byzantines and Turks have all inhabited various parts of Anatolia over the last couple of millennia. This multiculturalism and pluralism has been stated as being appreciated and as very important in Turkey (Uğur, \& Canefe, 2004). The Dutch scholar Gerrit Steunebrink has even stated that although Turkey lacks individual pluralism, it had collective pluralism in which a whole new identity was needed after the collapse of the Ottoman State in 1922 (Steunebrink, \& Van Der Zweerde, 2004).

\section{Historical Context in Turkey}

The historical context in which nationalism emerged in Turkey is tied directly to the lost wars of the Ottoman State during the $18^{\text {th }}$ and $19^{\text {th }}$ centuries. It led to disintegration, dissatisfaction but also an orientation to the Western model of a nation. The lost battles became even more painful when they resulted in lost wars that also paved the way for areas and regions to be lost; especially when it were provinces of the Ottoman State which were considered to be the epicenter.

But this is just one minor example of why the Balkans would have been so significant to the new regime; subsequently the political leaders of the Republic of Turkey. According to Zürcher (2010), the insurrection in the Balkans of 1912-1913 is even one of the main reasons why the old Ottoman regime fell. Within the Ottoman State this was also a highly debated issue:

"On the edges of the empire, the Ottomans lost control of Tunisia, Libya, Egypt, Crete, Cyprus, and parts of Caucasia. None of these areas were seriously contested by them as none were critical to the continued survival of the empire itself. In the Balkans, however, parts of which had been under Turkish domination for over five hundred years, the Ottomans fiercely contested the loss of power and control of the area" (Erickson, 2003).

These lost lands in the Balkans essentially formed the characteristics of the group who led the process of nationbuilding in Turkey. It becomes quite clear that there is a period of time when the Balkans are the political core of the Ottoman State. If we look at the period of the modern 
Republic of Turkey, one can see that it was founded in 1923 but the political ideologies seem to have come from movements in the years prior to its formation and in particular, from those political movements that originated in the Balkans. But despite the western orientation of these political movements, they were not exponents of a wealthy middle class, but were ethnically diverse military officers and army soldiers. It was not a colonial situation in which they were operating. Against this background, the İttihat ve Terakki Cemiyeti (or Young Turk Movement) emerge as an innovative new political movement in the last days of the Ottoman State. This Young Turk regime is also dubbed 'Ittihat ve Terakki Cemiyeti' and is translated by some scholars (Zürcher, 2004; Üngör, \& Polatel, 2011) as 'The Committee of Union and Progress' and (shortened as CUP). However, this paper employs either the original term 'Ittihat ve Terakki Cemiyeti' (translated more correctly as the 'Society of Unity and Progress') or the term 'Young Turks'. The Young Turks, made up primarily of Ottoman army officers and governmental officials, were desperately trying to save the Ottoman State in its decline; which had became imminent by the nineteenth century when the important Ottoman province of Greece was lost. Greece thereafter played a decisive role in the shaping of 'a Turkish national citizenship' (Van Meurs, \& Mungu-Pippidi, 2010). General feelings of despair and hope were channeled into ideologies that aimed at saving the Ottoman State from disintegrating and from falling into the hands of foreign occupiers. By 1908 the Young Turks, having their base in the Balkan region, had seized power in the Ottoman State in an attempt to save it from disintegration.

Although the Young Turks tightened their grip upon Ottoman territory in a desperate attempt to forge unity between Ottoman citizens, they could not avoid being sucked into the First Balkan War of 1912. In this war, the Balkan subjects of the Ottoman State secretly forged an alliance and simultaneously revolted which subsequently led to their independence. Through pure perseverance the Young Turks were able to recapture some parts of the Balkans, like the former Ottoman capital of Edirne, during the Second Balkan War of 1913 (Ahmad, 1993).

However, in general, the Balkan Wars proved disastrous for the Young Turks and for the Ottoman State. For example, from Greece alone some 200.000 Turks fled as (political) refugees from the lost provinces to the Anatolian mainland prior to 1912 in fear of torture and of ethnic cleansing, after the Greek rebel army occupied former Ottoman lands (Halaçoğlu, 1995). During the Balkan Wars an additional number of at least 410.000 refugees were added to these waves of migration (McCarthy, 1995). The Turkish minorities that stayed behind in the Balkans are the descendants of the Balkan refugees that were subjected to ethnic cleansing and forced assimilation. Despite this fact, Bulgaria (to name just one Balkan country as a example) with a population of approximately 7 million inhabitants still contains a minority of between 10 to $15 \%$ to at least $20 \%$ Turks (Turan, 1998).

Consequently the disastrous Balkan Wars of 1912-1913 enabled the Ottoman minorities to create their own independent states. The Greeks, Bulgarians and Serbs were the main examples. But the Ottoman State also encountered a wave of political refugees that poured into Anatolia. These refugees, mostly of Muslim and Turkish descent, brought with them their own ideas of nationalism, after seeing the minority nationalism which had resulted in them being driven from their own lands.

In reaction to both the minority nationalism that had started centuries earlier and had now evolved into a rebellion against the Ottoman State, as well as the refugees that fell victim to these rebellions; a process of nationbuilding was concocted in which militarism and pluralism were combined. Some nationalist minorities rebelled against this process of nationbuilding and subsequently tried to form their own nationbuilding through a homogenous form of historio- 
graphy. In Anatolia, however, the main focus became geography.

\section{A Concluding Overview}

Within the process of nationbuilding in Turkey, the characteristics of militarism and pluralism became key elements of the Turkish image of a nation. In order to further strengthen this image, the aspect of neglect and of emphasis within historiography was put to work. Anatolia was emphasized as the undisputed 'homeland' of the Turks. This emphasis in Turkish historiography (more specifically the history school books that are used in Turkish education) has been of such a nature that both Anatolia and the various tribes in Central Asia were all seen as 'Turkish'. Despite this, Turkish historiography is centered with a geographical emphasis.

When we look at the history as described by Turkish historiography in the three statistical modes, we can see three main conclusions to this research in accordance with the data collected from Su, \& Bülkat, 1961; Yıldız, 2006; and Arıca, \& Yaşasınoğlu, 2010. First of all; Anatolia as a geographical region in Turkish history stands out, both in ancient times (with the Hittites) as during other periods, as in contemporary times. Secondly; although the region of Central Asia is depicted as the 'ancient homeland of the Turks', especially in early ages until approximately the tenth or eleventh century, every tie between that region and the present-day Turkish inhabitants of the Republic of Turkey has been cut, through mentioning that Central Asia has altered in such a way that it has vanished from history. Thirdly and lastly, it has became clear that the region of the Balkans are left out; subsequently downplayed at some points and even neglected in other topics. The reason for downplaying Central Asia is given in the schoolbooks, but an explanation for neglecting the Balkans is not given. While these are the outcomes of Turkish historiography, it is important to take the aspect of the Balkans and to verify the outcomes regarding this region with the historiography in general to see what could be the possible explanation for neglecting the Balkans. As we have seen earlier, Turkey has many unresolved, neglected and excised cases of nationbuilding. All of these examples portray the problem with the Turkish concept of nationbuilding and the role of historiography as a part of this process of nationbuilding. Therefore the role of Turkish historiography needs to be further discussed.

One can see that what is left out in Turkish historiography: in the (at least three) millennia prior to the Seljuks, the Central Asian tribes took other routes to Europe in their process of migrating west. In doing so, these Central Asian (or Turkic) tribes could have passed through other regions then Anatolia and may even have settled there. It seems that these aspects were left out in Turkish historiography; for instance the event in which the Seljuks were defeated by the Mongol hordes in the thirteenth century and that they subsequently fled to Western Anatolia and the Balkans. This caused the epicenter of the Ottoman Sultanate (the successor of the Seljuks) to be in those regions, as well as their focus to be upon those provinces (Kiel, 1993). Subsequently, in the fourteenth century the Ottomans penetrated more into the Balkans than into any other region (Freely, 2008). This seemingly gives fuel for the conclusion that the region of the Balkans is seemingly neglected, left out or simply downplayed in Turkish historiography.

It is necessary to fill all of these gaps in Turkish historiography by using historiography in general to see which aspects of the Balkans are neglected in Turkish historiography and what role the Balkans played in Turkish history from ancient times to the Middle Ages. In this historiography the use of non-Turkish sources is clearly seen. It raises the question as to why Turkey is mostly fixated on the west (in particular Europe), which can be answered with a reference to the pluralism in Turkey. Seeing that Turkey has a lot of inhabitants of non-Turkish descent, this is not surprising. The fact that the Young Turks also originate from the European Balkans is another important factor. Members of the Young Turk movement later went on to 
create the modern Republic of Turkey in 1923, based upon principles that were formed outside of Anatolia.

Even in earlier times, Anatolia was never that important as a geographical reference point in Turkish history. For Turkey, geography is very different from that of the peoples of Europe. Being the offspring of nomads, it is difficult for the Turks to pinpoint exactly which regions are their homelands. Therefore the creation of a homeland is something that must be forged prior, or at the same time, as the efforts to unite the people through one dominant culture. Since European people settled in their geographical regions almost two millennia ago, their geographical tie is much stronger then it is in the case for the Turks. Even with the Seljuks or Ottomans, the Turks never really settled but were always on the move to secure more migration areas throgh victories and the conquest of other lands. This is also why around 1255 travelers mention that "Christians in Seljuk Anatolia outnumber the Muslims who rule over them, by ten to one" (Jackson, 2005, 348).

Nonetheless, in the case of Turkey, the region of Anatolia seems to have been chosen as the undividable core of the Turkish nation ever since the Seljuk tribes entered the stage in the eleventh century. Although the Seljuks dominated the entire Middle East (from Arabia to the borders of India), they also subsequently conquering Anatolia from the Byzantines at the Battle of Manzikert in 1071 (Freely, 2008). This single battle is hailed in Turkish school text books as the decisive moment for Turkish entry into Anatolia, never to leave this region again (Arıca, \& Yaşasınoğlu, 2010). If one region is downplayed or neglected in Turkish historiography, there must be a reason for this.

If we would now compare the aspect of nationbuilding in other countries, such as France and Britain, with what seems to be implemented in Turkey; we can see one common feature. As the aspect of colonization or of slavery is neglected in the history of western countries, a consequence of the process of nationbuilding, Turkey seems to neglect some geographical parts of its history. The reason for this seems to lie in the happenings in those areas; and subsequently the ethnic cleansing directed at Turkish citizens of the Ottoman State during the Balkan Wars.

Nonetheless, this aspect of ethnic cleaning directed at the Turks is either downplayed or is left out in contemporary Turkish nationbuilding. If we keep in mind that in the eighty-eight years since those wars, no critical analysis that examines the specific reasons for Ottoman defeat has ever been conducted, let alone other aspects, we can clearly see this neglect in contemporary historiography (Erickson, 2003). Therefore the Balkan Wars, the refugees from this war and all of its influence upon both the Anatolian mainland and the subsequent Republic of Turkey are effectively neglected and/or ignored. The aspect of 'victimized Turks' seemingly does not fit within the picture of the 'glorious Turkish military-nation' that was depicted immediately after 1923 during the process of Turkish nationbuilding, and therefore it was accordingly neglected.

One consequence of this aspect of neglect in the process of Turkish nationbuilding, is that it has caused massive discussion about certain events in Turkish history about which the modern Republic of Turkey does not wish to talk. The Armenian issue is one of those questions that has been neglected by Turkey for decades and was accompanied by silence for many years on the part of Turkey. Accordingly, the influence of the Balkan Wars on one of the main unresolved issues of modern-day Turkey can be seen as an important factor as to what can happen if nations keep neglecting an aspect of their history in order for their process of nationbuilding to succeed.

From 1923 to approximately the 1970s and 1980s, both the Balkan tragedies and the Armenian issue was kept quiet in Turkey. This caused many scholars to make assumptions regarding this neglected aspect, despite the fact that it seems somewhat early to jump to 
conclusions (Zürcher, 2004; Akçam, 2006; Akçam, 2007; Üngör, 2011). The Armenian issue is seen by some scholars as a byproduct of the anguish that the Balkan refugees brought with them after they were subjected to ethnic cleansing and suffering themselves; seemingly the Young Turks became bitter "after their expulsion from their ancestral lands in the Balkans, their emotions included humiliation, helplessness, anger, loss of dignity, lack of self-confidence, anxiety, embarassment, shame (sic)" (Üngör, \& Polatel, 2011, 25). To which account is this portrayal accurate? Almost no historical event is as controversial as the Armenian issue of 1915; it is today strongly debated if the Armenian relocation of 1915 was in fact a systematic act of the Young Turk regime within the Ottoman State to commit genocide or not.

Since scholars like Üngör and Polatel seem to take into account the aspect of the Balkan Wars to explain what happened during 1915, it is important to take this as a case study by future scholars to establish what happens when a historical case is neglected. During this case study, a historical overview of what happened in those years, according to variously primary sources as well as literature written by internationally renowned scholars, will be needed. It should be noted that this should in no way be written to take a stance on this highly disputed subject. It should only used as a case study in order to set up categories in which scholars that have occupied themselves with the Armenian issue in the late Ottoman period (and published their research findings as books, essays and/or papers), can be incorporated.

In order to for us to know more about what this meant for modern Turkey, there needs to be an accurate picture of the Balkan region, the Balkan Wars and their influence upon modern Turkey. For instance; although the Balkans are neglected in contemporary Turkish historiography, it had a significant role in Turkish history from ancient times into the Middle Ages. After having painted this picture, it will be possible to understand the absence of the Balkan territories in Turkish historiography. Of course it stems from the need to create nationbuilding in the modern Republic of Turkey, but one must also carefully try to ask ourself why the Balkan Wars were perceived to be of such a painful nature that they were neglected in the process of Turkish nationbuilding. Because basically; in both the Balkan Wars and the Armenian issue, Ottoman Turks were faced with major defeat, ethnic cleansing and tragedy which were impossible to fit within the image of the 'grand Turk'.

Thereafter, it will indeed be possible to verify that the absence of the Balkan territories in Turkish historiography stems from the need to create nationbuilding in the modern Republic of Turkey. In doing so this paper adds value to the field of study concerning the process of nationbuilding in Turkey. This added value is primarily due to the use of Turkish school text books as a sources for Turkish historiography, which itself is based upon non-Turkish historiography, but also the use of non-Turkish historiography in demonstrating the neglect and particular emphasis in Turkish historiography. In doing so, the case of Turkey is shown to be special. The rarity of the combination of militarism with pluralism in the process of nationbuilding, and the particular interpretation of the concept of nation, especially by the Young Turks, is what makes Turkey a case to remember when it comes to the matter of nationbuilding. 


\section{REFERENCES}

Adhikari, S., \& Mukul Kamle, M. (2010). "The Kashmir: An Unresolved Dispute Between India and Pakistan”. Geopolitics Quarterly, VI/4, 58-107.

Ahmad, F. (1993). The Making of Modern Turkey. London: Routledge.

Akçam, T. (2006). A Shameful Act: The Armenian Genocide and the question of Turkish responsibility. New York: Metropolitan.

Akçam, T. (2007). De Armeense Genocide: een reconstructie. Amsterdam: Nieuw Amsterdam.

Almond, G., \& Pye, L. (eds. 1965). Comparative Political Culture. Princeton: Princeton University Press.

Altınay, A. G. (2004). The Myth of the Military-Nation: Militarism, Gender, And Education in Turkey. New York: Palgra, \& Macmillan.

Anderson, B. (1991 [1983]). Imagined Communities: Reflections on the Origins and Spread of Nationalism. 2nd edition. London: Verso.

Arıca, S. T., \& Yaşasınoğlu, A. (2010). Çeyrek Asrın Soruları: Tarih Çıkmış 1985-2010 Soruları, (The Questions of a quarter century: History questions between 1985-2010). Ankara: Örnek Yayınevi.

Baykara, T. (2000). The Meaning of Turk: Turk's Brief History and Present. Ankara: Atatürk Culture Centre.

Belge, M. (2010). “Genç Kalemler and Turkish Nationalism”. Eds. Kerslake, C., Öktem, K., \& Robins, P. Turkey's Engagement with Modernity: Conflict and Change in the Twentieth Century, 27-37. Hampshire: Palgrave Macmillan.

Berkes, N. (1959). Turkish Nationalism and Western Civilization. Connecticut: Greenwood Press.

Bozdoğan, S. (2001). Modernism and Nation Building: Turkish Architectural Culture in the Early Republic. Washington: University of Washington Press.

Bozkurt, İ. (2002). "Kıbrıs'ın Tarihine Kısa Bir Bakış”, (A Short View of the History of Cyprus). Eds. İ. K. Ülger, \& E. Efegil. Avrupa Birliği Kıskacında Kıbrıs Meselesi: Bugünü ve Yarını, 9-15. ('The Cyprus Issue in the grip of the European Union: the present and the future). Ankara: Ahşen Yayıncilık.

Cassirer, E. (2009). The Myth of the State. Connecticut: Yale University Press.

Chickering, R. (2008). “Militarism and Radical Nationalism”. Ed. J. Retallack. Imperial Germany 18711918, pp. 196-218. Oxford: Oxford University Press.

Clark, B. (2006). Twice a Stranger: How Mass Expulsion Forged Modern Greece and Turkey. London: Granta.

Colchester, M. (2011). "Divers Paths To Justice: Legal pluralism and the rights of indigenous peoples in Southeast Asia: An Introduction”. Eds. M. Colchester, \& S. Chao. Divers Paths To Justice: Legal pluralism and the rights of indigenous peoples in Southeast Asia, 17-39. Chiang Mai: AIPP.

Collins, A., \& Gobineau, A. (2010). The Inequality of Human Races. Charleston: Nabu Press.

Dilaçar, A. M. (1936). Les bases Bio-Psychologiques de la Theorie Güneş Dil. İstanbul: Fazilet Basimevi.

Dismorr, A. (2008). Turkey Decoded. Beirut: Saqi.

Dixon, J. M. (2011). Changing the State's Story: Continuity and Change in Official Narratives of Dark Pasts. Unpublished dissertation. Berkeley: University of California.

Duran, B. (2005). "Islamist redefinition(s) of European and Islamic identities in Turkey”. Eds. Uğur, M., \& Canefe, N. Turkey and European Integration: Accession Prospects and Issues, 125-146. New York: Routledge.

Erickson, E. J. (2003). Defeat in Detail: The Ottoman Army in the Balkans, 1912-1913. Connecticut: Praeger.

Eriksen, T. H. (1993). Ethnicity and Nationalism: Anthropological Perspectives. Connecticut: Pluto Press.

Freely, J. (2008). Storm on Horseback: The Seljuk Warriors of Turkey. New York: I.B. Tauris.

Geary, P. J. (2003). The Myth of Nations: The Medieval Origins of Europe. Princeton: Princeton University Press.

Gellner, E. (1983). Nations and Nationalism. New York: Cornell University Press. 
Gobineau, A. de (1999). The Inequality of Human Races. (translation of 'Essai sur l'inégalité des races humaines', 1853-1855). New York: Howard Fertig.

Gobineau, J. A. C. de (1853-1855). Essai Sur l'inégalité des Races Humaines. Paris: Librairie de Firmin Didot Frères.

Gökalp, Z. (2001 [1923]). Türkçülüğün Esasları. İstanbul: İnkilap.

Halaçoğlu, A. (1995). Balkan Harbi Sirasında Rumeli'den Türk Göçleri (1912-1913), (Turkish Migrations from the former Ottoman province of South-Balkan during the Balkan Wars in 1912-1913). Ankara: Türk Tarih Kurumu.

Hanioğlu, M. Ş. (2008). A Brief History of the Late Ottoman Empire. Princeton: Prince University Press.

Hayes, C. (1931). The Historical Evolution of Modern Nationalism. New York: Smith.

Heart, M. Y. H. B., \& DeBruyn, L. M. (1998). "The American Indian Holocaust: Healing Historical Unresolved Grief”. American Indian Alaska Native Mental Health Research: journal of the National Centre, VIII/2, 56-78.

Hewitson, M. (2006). "Conclusion: Nationalism and the Nineteenth Century”. Eds. T. Baycroft, \& M. Hewitson. What Is a Nation?: Europe 1789-1914, 312-355. Oxford: Oxford University Press.

Higham, N. J. (2002). King Arthur, Myth-Making and History. London: Routledge.

Hobsbawm, E., \& Ranger, T. (1983). The Invention of Tradition. Cambridge: Cambridge University Press. Hobsbawm, E. (1990). Nations and Nationalism Since 1780. Cambridge: Cambridge University Press.

Iordachi, C. (2006). “The Ottoman Empire: Syncretic Nationalism and Citizenship in the Balkans”. Eds. T. Baycroft, \& M. Hewitson. What Is a Nation?: Europe 1789-1914, 120-151. Oxford: Oxford University Press.

Iordachi, C. (2010). "The Making of Cirizenship in the post-Ottoman Balkans: State Building, Foreign Models, and Legal-Political Transfers”. Eds. Van Meurs, W., \& Mungu-Pippidi, A. Ottomans into Europeans: State and Institution-Building in South Eastern Europe, 179-220. London: Hurst.

İnalcık, H. (2002). "Foundations of Ottoman-Jewish Cooperation”. Ed. Levy, A. Jews, Turks, Ottomans: A Shared History, Fifteenth Through the Twentieth Century, 3-14. Syracuse: Syracuse University Press.

İrem, K. (2009). Türkiye. Ankara: Fersa.

Jackson, P. (2005). The Mongols and the West. Edinburgh: Pearson Educated Limited.

Karaömerlioğlu, A. (2010). "The Role of Religion and Geography in Turkish Nationalism: The Case of Nurettin Topçu”. Eds. Diamandouros, N., Dragonas, T., \& Keyder, Ç. Spatial Conceptions of the Nation: Modernizing Geographies in Greece and Turkey. New York: I. B. Tauris Publishers.

Keyder, Ç. (2005). “A History and Geography of Turkish Nationalism”. Eds. F. Birtek, \& T. Dragonas. Citizenship and the Nation-State in Greece and Turkey, 93-109. New York: Routledge.

Kiel, M. (1993). De Geschiedenis van Turkije in de Seldjoekse, Beylik en Osmaanse periode, (The History of Turkey in the Seldjuk, Beylik and Ottoman period). Utrecht: Unpublished paper when Kiel was professor at Utrecht University, 1-19.

Kinross, L. (2002). The Ottoman Centuries: The Rise and Fall of the Turkish Empire. New York: Perennial.

Kurt, Y. (1995). Pontus Meselesi, (The Pontus Issue). Ankara: T.B.M.M. Basımevi.

Kvergić, H. F. (1935). La Psychologie de Quelques Éléments des Langues Turques. Vienna: unknown.

Lewis, G. (1999). The Turkish Language Reform: A Catastrophic Succes. Oxford: Oxford University Press.

Loomis, R. S. (1956). “The Arthurian Legend before 1139”. Eds. R. S. Loomis, \& R. Sherman. Wales and the Arthurian Legend, 179-220. Cardiff: University of Wales Press.

Luckham, R. (1982). "French militarism in Africa”. Review of African Political Economy, IX/24, 55-84.

Mathiez, A. (1939). La Révolution française, volume 1/3. Paris: Colin.

McCarthy, J. (1995). Death and Exile: the Ethnic Cleansing of Ottoman Muslims, 1821-1922. Princeton: The Darwin Press.

McCarthy, J. (1997). The Ottoman Turks: an Introductory History to 1923. New York: Longman. 
McCarthy, J., Arslan, E., Taşkıran, C., \& Turan, Ö. (2006). The Armenian Rebellion at Van. Utah: Utah University Press.

McCormack, G. (2009). “History Too Long Denied: Japan’s Unresolved Colonial Past and Today's North Korea Problem”. The Asia-Pacific Journal, Volume: 29-1-09 (July 20th, 2009), 1-7. Retrieved on February 17th, 2012 from http://www.japanfocus.org/-Gavan-McCormack/3188.

Meinecke, F.(1922). Weltbürgertum und Nationalstaat: Studien zur Genesis des deutschen Nationalstaates. Munchen: R. Oldenbourg.

Momin, A. R. (1996). Cultural Pluralism, National Identity and Development: The Indian Case. In B. Saraswati. Interface Of Cultural Identity Development, 290. New Delhi: Indira Gandhi National Centre for the Arts.

Nagashima, D. (2006). Japan's Militarist Past: Reconciliation in East Asia? Yale Journal of International Affairs, Volume 2, Issue 1: Fall/Winter 2006, pp. 112-120. Retrieved on March 26th, 2012 from http://yalejournal.org/wp-content/uploads/2011/01/062111nagashima.pdf.

Ortayll, İ. (2007 [2004]). Ottoman Studies, 2. Baskl ( ${ }^{\text {nd }}$ Edition). İstanbul: İstanbul Bilgi University Press.

Özdemir, B. (2009). Süryanilerin Dünü Bugünü: 1. Dünya Savaşı'nda Süryaniler, (The Assyrians in the past and present: the Assyrians during the First World War). Ankara: Türk Tarih Kurumu Basımevi.

Palmer, A. (1992). The Decline \& Fall of the Ottoman Empire. New York: Barnes and Noble.

Quataert, D. (2006). The Ottoman Empire, 1700-1922, 2nd edition. Cambridge: Cambridge University Press.

Shaw, S. J. (1976). "History of the Ottoman Empire and Modern Turkey”. Volume I: Empire of the Gazis: The Rise and Decline of the Ottoman Empire, 1280-1808. Cambridge: Cambridge University Press.

Shaw, S. J., \& Shaw, E.K. (1977). "History of the Ottoman Empire and Modern Turkey". Volume II: Reform, Revolution and Republic: The Rise of Modern Turkey, 1808-1975. Cambridge: Cambridge University Press.

Shaw, S. J. (1991). The Jews of the Ottoman Empire and the Turkish Republic. New York: New York University Press.

Smith, A. D. (1991). National Identity. London: Penguin Books.

Smith, A. D. (2003). Nationalism and Modernism. New York: Routledge.

Smith, A. D. (2009). Ethno-Symbolism and Nationalism: A Cultural Approach. New York: Routledge.

Snyder, L. (1954). The Meaning of Nationalism. New Brunswick: Rutgers University Press.

Soboul, A. (1973). The French Revolution in Contemporary World History. Los Angeles: University of California.

Steunebrink, G., \& Van Der Zweerde, E. (2004). "Libarlism And Naitonalism In Europe And Turkey: On The Reception And Application Of Modern European Ideas In A New Historiocal And Cultural Context”. Eds. G. Steunebrink, \& E. Van Der Zweerde. Religion, Civil Society, and the Nation; Modernization in Intercultural Context: Russia, Japan, Turkey, 153-173. Amsterdam/New York: Rodopi.

Su, K., \& Bülkat, G. (1961). Illk ve Orta Okullar İçin Resimlerle Tarih Atlası, (History Atlas with Pictures for Elementary and Middle Schools). Ankara: Birsen Yayınevi.

Thorpe, L. (1966). Geoffrey of Monmouth: The History of the Kings of Britain. Harmondsworth: Penguin.

Turan, Ö. (1998). The Turkish Minority in Bulgaria (1878-1908). Ankara: Türk Tarih Kurumu.

Türkay, K. (1982). A. Dilaçar. Ankara: Ankara University Press.

Türközü, H. K. (1985). Türkmen Ülkesi (=Doğu Anadolu) Adı ve Emperyalizmin Etkileri, (The Term Türkmen Country (= Eastern Anatolia) and the Influence of Imperialism). Ankara: Türk Kültürünü Araştırma Enstitüsü.

Üngör, U. Ü. (2011). The Making of Modern Turkey: Nation and State in Eastern Anatolia, 1913-1950. Oxford: Oxford University Press.

Üngör, U. Ü., \& Polatel, M. (2011). Confiscation and Destruction: The Young Turk Seizure of Armenian Property. London: Continuum International Publishing Group.

Ünlü, M., \& Çotuksöken, Y. (2001). Türkçülüğün Esasları (Günümüz Türkçesiyle). İstanbul: İnkilap. 
Weber, E. (1976). Peasants into Frenchmen: The Modernization of Rural France, 1870-1914. California: Stanford University Press.

Yıldız, İ. (2006). ÖSS (Öğrenci Seçme Sınavı) Tarih: Temel Kavramlar ve Bilgiler, (Student Selection Exams History: Basic Terms and Knowledge). İstanbul: bry Yayınları.

Zürcher, E. J. (2010). "The Importance of Being Secular: Islam in the Service of the National and PreNational State”. Eds. Kerslake, C., Öktem, K., \& Robins, P. Turkey's Engagement with Modernity: Conflict and Change in the Twentieth Century, 55-68. Hampshire: Palgrave Macmillan.

Zürcher, E. J. (2010). The Young Turk Legacy And Nation Building: From the Ottoman Empire to Atatürk's Turkey. New York: I.B. Tauris.

Zürcher, E. J. (2004). Turkey: A Modern History. London: I. B. Tauris.

\section{APPENDIX}

Turkish history text books that were analyzed for geographical emphasis on Anatolia within Turkish history by the author in 2012:

Akşit, N., \& Oktay, E. (1986). Tarih: Lise I. Sinıf, (History: First Year of high school). İstanbul: Remzi Kitabevi.

Akşit, N. (1986). Tarih: Lise 2, (History: Second Year of high school). İstanbul: Remzi Kitabevi.

Arıca, S. T., \& Yaşasınoğlu, A. (2010). Çeyrek Asrın Soruları: Tarih çımııs 1985-2010 soruları, (The Questions of a quarter century: History questions between 1985-2010). Ankara: Örnek Yayınevi.

Dündar, O. (ed. 2009). Atatürk ve Cumhuriyetçilik, (Atatürk and Republicanism). Ankara: Genelkurmay Basımevi / Genelkurmay Askerî Tarih ve Stratejik Etüt Başkanlığı Yayınları.

Dürder, B., \& Ediskun, H. (1982). Bizim Dilbilgisi, İlkokul 5, (Our Language Grammer, Fifth Grade of Primary School). İstanbul: Remzi Kitabevi.

Göğüş, B. (1982). Temeleğitim Okulları Türkçe, 3. Sınıf, (Turkish for Primary School, Third Grade). İstanbul: Devlet Kitapları / Oğul Matbaacılık.

Göğüş, B. (1982). Temeleğitim Okulları Türkçe, 4. Sınıf, (Turkish for Primary School, Fourth Grade). İstanbul: Devlet Kitapları / Tifdruk Matbaacılık.

Göğüş, B. (1982). Temeleğitim Okulları Türkçe, 5. Sınıf, (Turkish for Primary School, Fifth Grade). Ankara: Devlet Kitapları / Türk Tarih Kurumu Basımevi.

Ortaylı, İ. (ed. 2004). Tarih Atlası, (History Atlas). İstanbul: Atlas / Hürriyet.

Ortaylı, İ. (ed. 2004). Tarih Atlası: İlk ve Ortaögretim İçin, (History Atlas: For Primary and Secondary Education). İstanbul: Atlas

Sanır, F., Asal, T., \& Akşit, N. (1981). İlkokullar İçin Sosyal Bilgiler, 4. Sınıf, (Social Sciences for Primary School, Fourth Grade). İstanbul: Devlet Kitapları / Milli Eğitim Basımevi.

Sanır, F., Asal, T., \& Akşit, N. (1978). İlkokullar İçin Sosyal Bilgiler, 5. Sınıf, (Social Sciences for Primary School, Fifth Grade). İstanbul: Devlet Kitapları / Milli Eğitim Basımevi.

Su, K., \& Bülkat, G. (1961). İlk ve Orta Okullar İçin Resimlerle Tarih Atlası, (History Atlas with Pictures for Elementary and Middle Schools). Ankara: Birsen Yayınevi.

Türkben, M. (ed. 2005). Dünya ve Türkiye Atlası, (The Atlas of Turkey and the World). İstanbul: Atlas / Milliyet.

Unat, F. R. (1983). Tarih Atlası, genişletilmiş basım, (History Atlas, extended version). İstanbul: Kanaat Yayınları.

Yıldız, İ. (2006). (Öğrenci Seçme Sınavı) ÖSS Tarih: Temel Kavramlar ve Bilgiler, (Student Selection Exams History: Basic Terms and Knowledge). İstanbul: Birey Yayınları. 